\title{
Climatic Effects on the Formation and Function of Architectures Based on the Climate in Semnan Province, Iran
}

\author{
Saeid Kamyabi ${ }^{1}$, Hooman Mesgarian ${ }^{2 *}$ \\ ${ }^{1}$ Department of Geography, Semnan Branch, Islamic Azad University, Semnan, Iran \\ ${ }^{2}$ Department of Geography, Islamic Azad University, Semnan Branch, Member of Young Researchers Elite Club, \\ Semnan, Iran \\ Email: ${ }^{*}$ mesgarian.eng@gmail.com
}

Received 15 April 2014; revised 12 May 2014; accepted 31 May 2014

Copyright (C) 2014 by authors and Scientific Research Publishing Inc.

This work is licensed under the Creative Commons Attribution International License (CC BY).

http://creativecommons.org/licenses/by/4.0/

(c) (i) Open Access

\section{Abstract}

Semnan province is one of the vast provinces of the country that has a variety of topographical and clamatorial conditions. This province plays a key role in industrial, agricultural and animal husbandry activities. The study of its climate potential with respect to its natural limitations like lack of water resources, soil types, droughts and desertification problems has been considered as a necessity in the province annual planning. In this study, the climatic regionalization of the province is done through using empirical and quantitative methods on climatic data of meteorological stations of the area in statistical period of 1982-2005. Methods of Koppen empirical, De Martonne, Emberger and Dr Karimi have divided the province into 3, 2, 4 and 6 climactic types, respectively. Using principle components and the cluster analysis on 14 climatic elements of 21 stations, 5 climatic types have been specified for the province. Based on this method, temperature, its Diurnal Temperature Range (DTR), precipitation and its type, and humidity contribute a great deal to the climate of the Semnan Province. The main results of this identification of 5 climatic types include hot \& dry, dry \& hot semi-dry, dry \& cold semi-dry, mountainous, and Caspian climate.

\section{Keywords}

Climate Potential, Principle Components, Cluster Analysis, Semnan Province

\section{Introduction}

One of the most important factors that have a significant impact on construction of human residences at all

"Corresponding author.

How to cite this paper: Kamyabi, S. and Mesgarian, H. (2014) Climatic Effects on the Formation and Function of Architectures Based on the Climate in Semnan Province, Iran. Open Journal of Ecology, 4, 543-553. 
places and times is the climatic specifications and climate conditions. The conducted researches about climatic adaptability in Iran mainly deal with bio-climatic zones and less attention has been paid to climatic adaptability of the residences per case [1]. Also one of the most important factors which impede movement toward sustainable architecture is the shortage of the basic information which is necessary to explain the correct construction models. Study of the climatic conditions of different regions is essential for development affairs and regional planning and it is inevitably necessary to design the construction where the issue of sustainable design is raised [2]. Climatic zoning system is a method in which the different areas that have things in common are put them together in one single zone as far as different climatic aspects such as type, chronological distribution of temperature, precipitation, plant coverage, etc. are concerned. Climatic zoning has its own definition at different scales including international, regional and national [3]. The applied methods to determine it depend on the up-to-date knowledge at every period of time. In the past, the Greek divided the earth into three climatic regions using important orbits such as equator, tropic of cancer and polar orbit of the earth. In the beginning of the past century, many qualitative and experimental methods such as Kacup, Humboldt, Torrence White and Pennman were common. Since when Pennman presented a new method based on physics to make climatic classification, use of qualitative methods in climatic zoning developed. From then on, experimental resistance methods in which classification criterion and threshold was pre-defined left its place to quantitative dynamic methods where the criterion and thresholds determine the problem conditions. Among all, the statistical methods, particularly multivariate ones such as cluster analysis and factor analysis play an important role to determine the climatic borders [4].

The experts of the country have used experimental methods frequently in the climatic zoning of different areas.

[5] divided 15 meteorological stations in Azerbaijan to five separate areas during the statistical period of 1950-1977 using two elements of temperature and precipitation as the determining factors of the climate and Koppen method. [6] divided the state climate into dry and semi-dry climates using Koppen method. Alijani, 1997, divided the climatic regions of Iran on the basis of two variables, namely, annual precipitation and number of freezing days into six categories and marked them on the map of Iran.

They used different methods to study climate in various parts of the world and Iran. [6], created a climatic zoning of the West Africa using 17 climatic variables and 109 meteorological stations during the statistical period of 1931-1971. [7] Divided England into 10 distinct climatic zones using 16 agroclimatic variables during the statistical period of 1941-1970. [8] created a climatic zoning of Australia using the data of 28 climatic variables in a 30-year statistical period from 1930-1960. [9] did the same using 24 climatic elements and 147 meteorological stations in part of the US. [10], divided Iran into 6 main regions and 12 sub-regions using 49 climatic variables using 43 meteorological stations in the period from 1961-1990, applying factor analysis and cluster analysis methods under geographical and climatic variables in 77 meteorological stations. They described the characteristics of each climate separately. [6] Conducted similar studies of the northwest Iran including Aras River and Uromia Lake, [6] also conducted similar studies of the northwest to southwest Iran. There have been studies conducted in Iran for a long time and the first study of this type was Dr Ganji's climatic classification in 1995. He presented the first climatic classifications according to the suggested methods and formula of Con. Jamshid Riazi also provided the first climatic classification for construction purposes in Iran in 1977. He did it according to Olgi method using the statistics and data from 43 synoptic stations, but unfortunately Jamshid Riazi”s job could not attract much attention because the role of construction elements to control the conditions of internal spaces is not clear in Olgi's method. [11] Identified different climates of Iran for housing and architecture purposes, using the suggested constructional and biochemical table by Guini. [9] Explained the role of climate in housing design in an article and provided suggestions for climatic design of Tabriz using the methods of Olgi, Guini and Mahani [11], assessed the bio-climate and heating needs of buildings in Tabriz and [11] also presented a research report under the title of "impact of climatic elements on human being" to the State Meteorology Organization. Hassan Hassani's thesis with regard to the relationship between climate and architecture in Rasht, 2003 was another example. In the current study, the climatic zoning of Semnan province whose area is $95,815 \mathrm{sq}$ kilometer (8.5\% of the total area of the country) and has special characteristics as far as time and place dimensions are concerned is produced (Management and Planning Organization, Semnan Province, 2004). In this study, climatic specifications of the earth in 21 meteorological stations of the province (synoptic, climatologically and pluviometric) and 14 climatic components from 1982-2005 using the qualitative (experimental) methods of Koppen, De Martonne, Emberger and Dr Karimi as well as quantitative, analytical and factor methods (principal components) and cluster analysis were used. 


\section{Materials and Methods}

Climatic classification and indices identify the climatic conditions of each region by assessing the meteoric components in long-term periods. Hence the first step in this study will be to prepare the long-term and effective statistics on meteoric and climatic situation in meteorological stations. For this purpose, the data of meteorological stations that have common statistical periods and cover the entire province were used. These climatic data consists of temperature, precipitation, relative humidity and number of freezing days in 21 meteorological stations (synoptic, climatologically and pluviometric) of the province and its neighboring stations. The data was extracted from the General Department of Machine Services of the State Meteorology Organization during the statistical period of 1982-2005. The Zonings of the south half of the province were abandoned due to insufficient converge of stations in that region. Prior to doing the data analysis, the quality of the data was studied using double mass method as far as compatibility is concerned. Then the lost data was estimated using Interpolate method. Using the existing climatic data and applying qualitative methods of Koppen, De Martonne, Emberger and Karimi as well as quantitative method (factor analysis and cluster analysis) in addition to SPSS 21 statistical software and Geographical Information System (GIS), the climatic zoning of the province was completed.

\section{Research Findings}

\subsection{Koppen Classification Method}

According to Koppen method, three climatic types, namely, desert, steppe and humid were identified. The border between each of these climates, for example the border between desert and steppe and or the border between steppe and humid depend on the degree of temperature and the amount and time of annual precipitation.

Using this method, 10 meteorological stations in Semnan, holding the specifications of the main "B" group were selected. The climate of " $\mathrm{B}$ ” group is dry as far as Koppen is concerned because the amount of evaporation and perspiration is more than the amount of precipitation and there is no extra water in the region. In this group, the amount of precipitation cannot be used as the only factor to determine the limits of " $B$ " climate because the impact of precipitation to supply the required humidity for the growth of plants depends on the amount of evaporation and perspiration. Thus, the season of maximum precipitation was also used to determine the climatic type in addition to the annual temperature and precipitation. Considering this criterion, the climate of " $\mathrm{B}$ ” group is divided into two climatic sub-groups, i.e., dry and desert climate (BW) and semi-desert and steppe climate (BS). The stations of the province are also divided into two sub-groups, namely dry climate (BW) and semi-dry climate (BS) and generally speaking, there are three climatic types as per Table 1 . In order to identify better the regions of the third factor in two forms, " $k$ " indicates the average annual temperature which is less than 18 degree centigrade and " $\mathrm{h}$ ” indicates the average annual temperature which is equal to or more than 18 degree centigrade. According to Koppen classification, Semnan, Garmsar, Ivanaki and Hassinan (central parts in the margin of Kavir desert) have BWh climatic type which is dry, desert and warm, and Shahroud, Sodaghlan, Mehdishahr, Majan and Nardin (north and northeast of the province) have BSk climatic type which is steppe or semi-desert and Biarjomand has BWh climatic type which is dry, desert and cold.

\subsubsection{De Martonne Method}

In De Martonne method, the equation in form of the presented dry coefficient could be used in a multi-day, one month, one season and one year term basis.

In Equation I (1), I is the index of dry coefficient, $\mathrm{p}$ is the average annual precipitation (mm) and $\mathrm{T}$ is the average annual temperature (centigrade degree).

According to De Martonne method, among the selected stations of the province, only Sodaghlan, Mehdishahr and Majan (north and northeast regions) have semi-dry climates and other parts of the province have dry climate (Table 2).

\subsubsection{Classification Method}

Emberger presented an image of climate according to his experiences and this image has two perpendicular axes. The horizontal axis is the amount of temperature according to centigrade degree $(\mathrm{m})$ and the vertical axis is the amount of Q2 coming from formula No. 2 [12]. 
Table 1. Climatic types of selected stations according to Koppen method.

\begin{tabular}{cccccccccc}
\hline $\begin{array}{c}\text { Name of } \\
\text { Station }\end{array}$ & $\begin{array}{c}\text { Average } \\
\text { annual } \\
\text { temperature } \\
\left({ }^{\circ} \mathrm{C}\right)\end{array}$ & $\begin{array}{c}\text { Average } \\
\text { temperature of } \\
\text { the coldest month } \\
\text { of the year }\left({ }^{\circ} \mathrm{C}\right)\end{array}$ & $\begin{array}{c}\text { Average } \\
\text { temperature } \\
\text { of the hottest } \\
\text { month of the } \\
\text { year }\left({ }^{\circ} \mathrm{C}\right)\end{array}$ & $\begin{array}{c}\text { Annual } \\
\text { precipitation } \\
\text { amount } \\
(\mathrm{mm})\end{array}$ & $\begin{array}{c}\text { Amount of } \\
\text { precipitation } \\
\text { in the driest } \\
\text { month of the } \\
\text { year }(\mathrm{mm})\end{array}$ & $\begin{array}{c}\text { Amount of } \\
\text { precipitation } \\
\text { in the most } \\
\text { humid } \\
\text { month (mm) }\end{array}$ & $\begin{array}{c}\text { Maximum } \\
\text { seasonal } \\
\text { precipitation amount }(\mathrm{mm})\end{array}$ & $\begin{array}{c}\text { Seasonal } \\
\text { Precipitation }\end{array}$ & $\begin{array}{c}\text { Climatic } \\
\text { type }\end{array}$ \\
\hline Semnan & 2.18 & 2.4 & 7.31 & 7.145 & 4.1 & 9.2 & Winter & 9.65 & BWh \\
Shahroud & 15 & 1.2 & 3.27 & 4.159 & 8.1 & 33 & Winter & 1.70 & BSk \\
Garmsar & 5.18 & 8.4 & 9.31 & 9.127 & 1.0 & 29 & Winter & 2.56 & BWh \\
Biarjomand & 16 & 6.2 & 29 & 7.124 & 8.0 & 9.27 & Winter & 9.49 & BWk \\
Ivanaki & 2.19 & 3.6 & 8.31 & 3.151 & 3.0 & 7.28 & Winter & 3.51 & BWh \\
Hassinan & 3.21 & 7.7 & 6.33 & 162 & 0 & 18 & Winter & 6.42 & BWh \\
Sodaghlan & 3.15 & 9.0 & 5.21 & 6.407 & 17 & 63 & Spring & 6.130 & BSk \\
Mehdishahr & 5.12 & 3.0 & 9.24 & 253 & 7.5 & 6.40 & Winter & 6.86 & BSk \\
Majan & 6.10 & -1.1 & 5.21 & 4.291 & 6.6 & 7.52 & Spring & 2.98 & BSk \\
Nardin & 8.11 & 2.1 & 4.21 & 9.178 & 1 & 3.33 & Spring & 7.56 & BSk \\
\hline
\end{tabular}

Table 2. Climatic types of selected stations according to De Martonne method.

\begin{tabular}{ccccc}
\hline Name of station & $\begin{array}{c}\text { Temperature average } \\
(\mathrm{T})\left({ }^{\circ} \mathrm{C}\right)\end{array}$ & $\begin{array}{c}\text { Precipitation average } \\
(\mathrm{P}) \mathrm{mm}\end{array}$ & $\begin{array}{c}\text { De Martonne Temperature } \\
\text { Index (I) }\end{array}$ & Climatic type \\
\hline Semnan & 2.18 & 7.145 & 1.5 & Dry \\
Shahroud & 15 & 4.159 & 3.6 & Dry \\
Garmsar & 5.18 & 9.127 & 5.4 & Dry \\
Biarjomand & 16 & 7.124 & 8.4 & Dry \\
Ivanaki & 2.19 & 3.151 & 2.5 & Dry \\
Hassinan & 3.21 & 162 & 2.5 & Dry \\
Sodaghlan & 2.15 & 6.407 & 2.16 & Semi-dry \\
Mehdishahr & 5.12 & 253 & 2.11 & Dry \\
Majan & 6.10 & 4.291 & 1.14 & Dry \\
Nardin & 8.11 & 9.178 & 2.8 & Dry \\
\hline
\end{tabular}

$\mathrm{Q} 2=(2)$.

$\mathrm{Q} 2$ = Emberger climatic coefficient.

$\mathrm{M}=$ Average maximum temperature in the hottest month of the year according to Kelvin degree.

$\mathrm{m}=$ Average minimum temperature in the coldest month of the year according to Kelvin degree.

$\mathrm{P}=$ Average annual precipitation ( $\mathrm{mm})$.

Study and analysis of the above method, 5 stations in Semnan, Shahroud, Garmsar, Biarjomand, Mehdishahr and Nardin have the dry cold climate type, Ivanaki and Hassinan have mild desert climate, Sodaghlan station has semi cold and humid climate and Majan station has semi cold and dry climate (Table 3).

\subsubsection{Dr Karimi Method}

Dr Karimi, relying on his experiences, tried to present a method for Iran with regard to agriculture, water and agro climatology to be able to separate the potentials of the agricultural lands (water studies, agro climatology of Semnan, 1993). The climate of each region is calculated using the following formula:

$\mathrm{I}=(3)$.

In this equation, $I(3)=$ humidity coefficient of Dr. Karimi (percentage).

$\mathrm{P}=$ Total annual precipitation $(\mathrm{mm})$.

$\mathrm{T}=$ Total temperature degree of the months whose average monthly temperature is more than 10 degree centigrade. Since it was proved that total temperatures higher than 10 degree centigrade are effective on the growth of many plants, it was considered that the total temperatures higher than 10 degree centigrade were effective on growth of most plants. The climatic regions of Semnan province were divided into 6 types using Karimi method 
Table 3. Climatic types of selected stations according to Emberger method.

\begin{tabular}{ccccccccc}
\hline Station & $\begin{array}{c}\mathrm{P} \\
(\mathrm{mm})\end{array}$ & $\begin{array}{c}\text { Centigrade } \\
\text { degree }\end{array}$ & $\begin{array}{c}\text { Kelvin } \\
\text { degree }\end{array}$ & $\begin{array}{c}\text { Centigrade } \\
\text { degree }\left({ }^{\circ} \mathrm{C}\right)\end{array}$ & $\begin{array}{c}\text { Kelvin } \\
\text { degree }\left({ }^{\circ} \mathrm{K}\right)\end{array}$ & $\begin{array}{c}\text { Emberger } \\
\text { coefficient }\end{array}$ & Climatic type \\
\hline Semnan & 7.145 & 3.37 & 3.310 & 0 & 273 & 4.13 & Dry cold \\
Shahroud & 4.159 & 3.33 & 3.306 & -1.9 & 1.271 & 6.15 & Dry cold \\
Garmsar & 9.127 & 9.39 & 9.312 & -0.9 & 1.272 & 7.10 & Dry cold \\
Biarjomand & 7.124 & 3.35 & 3.308 & -9.2 & 1.270 & 2.11 & Dry cold \\
Ivanaki & 3.151 & 8.39 & 8.312 & 3.1 & 3.274 & 3.13 & Mild desert \\
Hassinan & 162 & 3.39 & 3.312 & 5.2 & 5.275 & 15 & Mild desert \\
Sodaghlan & 6.407 & 1.31 & 1.304 & -5 & 268 & 9.41 & Semi-humid cold \\
Mehdishahr & 253 & 5.27 & 5.300 & -8.4 & 2.268 & 5.24 & Dry cold \\
Majan & 4.291 & 8.28 & 8.301 & -7.3 & 3.269 & 7.31 & Semi-dry cold \\
Nardin & 9.178 & 8.28 & 8.301 & -7.3 & 3.269 & 2.19 & Dry cold \\
\hline
\end{tabular}

so that Semnan and Garmsar have dry climatic type, hot summers and slightly cold winters, Biarjomand has dry climate, hot summers and semi-cold winters, Ivanaki has dry climate, hot summers and mild winters, Hassinan has dry climate, very hot summers and mild winters, Sodaghlan, Mehdishahr, Majan and Nardin have semi-humid climatic types, mild summers and very cold winters and Shahroud has semi-dry climate, hot summers and semi-cold winters (Table 4).

\subsection{Quantitative Methods (Factor Analysis and Cluster Analysis)}

In recent decades, multivariate statistical methods such as factor analysis and cluster analysis have spread in meteorological and climatologically [12]. In factor analysis, some variables are not only reduced to some combined and merged factors, but also the amount of the existing initial variance (variety or diffraction) in principal data is maintained. The new factors in principal component analysis are called the principal component [9]. Cluster analysis is one of the multivariate methods which is used for grouping and classification of data. This method is used to make grouping of individuals of one sample and tries to classify similar individuals into special groups to form a separate class [13]. In fact, in this method, a set of individuals or members are classified and or clustered according to the degree of their similarities. In this method, it was tried that the clusters show two characteristics of separation outside and connection inside [9]. Statistically speaking, in this method, holding a sample of $N$ individuals and measuring $\mathrm{P}$ variable characteristics of each $\mathrm{n}$ individual, the individuals are classified into different groups and are put into one category considering the special conditions of the members holding similar characteristics [14]. Cluster analysis is a suitable instrument to clarify actual groups and to reduce the number of data. At each stage of clustering, the amount of deviation criterion both within the clusters and among them was calculated and compared using Equations (4) and (5) [14]:

$$
\begin{gathered}
\mathrm{K}^{-1} \times \mathrm{K}_{\mathrm{K}-1}\left(\mathrm{~S}_{\mathrm{K}}\right)=\mathrm{WCS} \\
\mathrm{BSC}=\left[(\mathrm{K}-1)^{-1.1} \times \mathrm{K}_{\mathrm{K}-1}\left(\mathrm{k}^{-}\right)^{2}\right]^{1.2}
\end{gathered}
$$

In Equation (4) and (5), WCS is the intra-group deviation criterion, BSC is the inter-group deviation criterion and $\mathrm{K}$ is the number of clusters of the groups. $\mathrm{K}$ is the average of each group or cluster, average of all clusters and deviation criterion of the desired variable in each of the clusters. At each stage, if the closer elements or clusters are merged, the amount of WCS will be lower and the amount of BSC will be higher. A table will be drawn beside each clustering analysis that expresses a suitable assumption of the data classification. This table firstly has branches in the number of observations and gradually these branches join each other proportionate to their distances and will end up meeting each other on the top of the main trunk of the tree. The final clusters are determined according to the collection of branches and then their distinction is measured through quantitative methods [15]. To use factor analysis method in climatic classifications at different time and place scales, there are 6 possible versions taking the fact that in all versions, there are the factors of climatic time such as temperature, precipitation, etc. and the factors of place (station location) [9]. R matrix mode is considered in climatic 
Table 4. Climatic types of selected stations according to Dr Karimi method.

\begin{tabular}{|c|c|c|c|c|c|c|c|}
\hline \multirow{2}{*}{ Station name } & \multirow{2}{*}{$\begin{array}{l}\text { Average annual } \\
\text { precipitation } \\
\text { (mm) }\end{array}$} & \multicolumn{2}{|c|}{$\begin{array}{l}\text { Warmness } \\
\text { coefficient }\end{array}$} & \multicolumn{2}{|c|}{ Coldness coefficient } & \multirow{2}{*}{$\begin{array}{c}\text { Humidity } \\
\text { coefficient }\end{array}$} & \multirow{2}{*}{ Climatic type } \\
\hline & & $\mathrm{T}\left({ }^{\circ} \mathrm{C}\right)$ & Sign & $\begin{array}{l}\text { Average of coldest } \\
\text { month of the year }\left({ }^{\circ} \mathrm{C}\right)\end{array}$ & Sign & & \\
\hline Semnan & 7.145 & 1.202 & $\mathrm{C}$ & 2.4 & 4 & 9.6 & $\begin{array}{l}\text { Dry, hot summers, slightly } \\
\text { cold winters }\end{array}$ \\
\hline Shahroud & 4.159 & 153 & $\mathrm{C}$ & 1.2 & 3 & 8.4 & $\begin{array}{l}\text { Semi-dry, hot summers and } \\
\text { semi-cold winters }\end{array}$ \\
\hline Garmsar & 9.127 & 4.203 & $\mathrm{C}$ & 8.4 & 4 & 9.7 & $\begin{array}{l}\text { Dry, hot summers, slightly } \\
\text { cold winters }\end{array}$ \\
\hline Biarjomand & 7.124 & 1.161 & $\mathrm{C}$ & 6.2 & 3 & 5.6 & $\begin{array}{l}\text { Dry, hot summers, } \\
\text { semi-cold winters }\end{array}$ \\
\hline Ivanaki & 3.151 & 1.209 & $\mathrm{C}$ & 3.6 & 5 & 7 & $\begin{array}{l}\text { Dry, hot summers, } \\
\text { mild winters }\end{array}$ \\
\hline Hassinan & 162 & 224 & $\mathrm{D}$ & 7.7 & 5 & 9.6 & $\begin{array}{l}\text { Dry, very hot summers, } \\
\text { mild winters }\end{array}$ \\
\hline Sodaghlan & 6.407 & 3.118 & B & 0.9 & 1 & 4.1 & $\begin{array}{l}\text { Semi-humid, moderate summers, } \\
\text { very cold winters }\end{array}$ \\
\hline Mehdishahr & 253 & 133 & B & 0.3 & 1 & 6.2 & $\begin{array}{l}\text { Semi-humid, moderate summers, } \\
\text { very cold winters }\end{array}$ \\
\hline Majan & 4.291 & 5.105 & B & -1.1 & 1 & 8.1 & $\begin{array}{l}\text { Semi-humid, moderate summers, } \\
\text { very cold winters }\end{array}$ \\
\hline Nardin & 9.178 & 1.107 & B & 2.1 & 2 & 9.2 & $\begin{array}{l}\text { Semi-humid, moderate summers, } \\
\text { very cold winters }\end{array}$ \\
\hline
\end{tabular}

classification where the number of columns is equal to the size of the used variables and the number of lines is equal to the number of the used station points (stations) as shown [9]. The quantitative amount in each special line and column indicates the amount of the variable (average variable in one common period) at one special station (place). Considering the different measurement scales of climatic variables, each variable is standardized according to the average and variance of that variable. In this study, 14 climatic variables including the parameters of temperature (average temperature, average maximum and minimum of temperature, average maximum and minimum of absolute temperature), relative humidity (average relative humidity, maximum and minimum average of relative humidity), long-term average of annual precipitation, 24-hour precipitation, the number of freezing days and the number of raining days were applied. Considering the fact that most of the regions of the province are located in desert areas, it was tried to use suitable coefficients to show the severe fluctuations of temperature and precipitation in this zoning. Two combined parameters of fluctuation scope of temperature (difference of the maximum and minimum temperature) as well as simple index of daily precipitation (the amount of precipitation divided by the number of raining days) which are suitable indicators for desert areas were used. The necessary statistical computations to determine the principal components (factors) and the factor loads including calculation of integrity matrix, variance, covariance and perpendicular (varimax) were made. It was tried in these computations to consider the necessary criterion for the correctness of the model. The results of the analysis show that four principal factors, namely temperature (52.54\%), precipitation and relative humidity (16.15\%), type of precipitation (10.47\%) and scope of 24.7 changes (7.52\%) with the total figure of $85.68 \%$ changes (Table 5) are considered the determining factors of the province climate in the period from 1984-2004 [16].

Following completion of the working stages of factor analysis, cluster analysis was applied using distance method and the criterion of Euclid distance over the grades of the principal components, i.e., calculated factor. The conducted clustering process resulted in separation of climatic regions in form of clustering stations. The results of the clustering analysis on the random sample of matrix of climatic factors are shown in 1421 dimensions and five climatic regions are identifiable in Semnan province according to Figure 1 as follows:

1) Hot and dry

This region is mainly located in south part of the province and north of central desert. The most prominent climatic characteristics of this region are in turn heat, high intensity and duration of sunlight and shortage of re- 
Table 5. Total squares of factor loads.

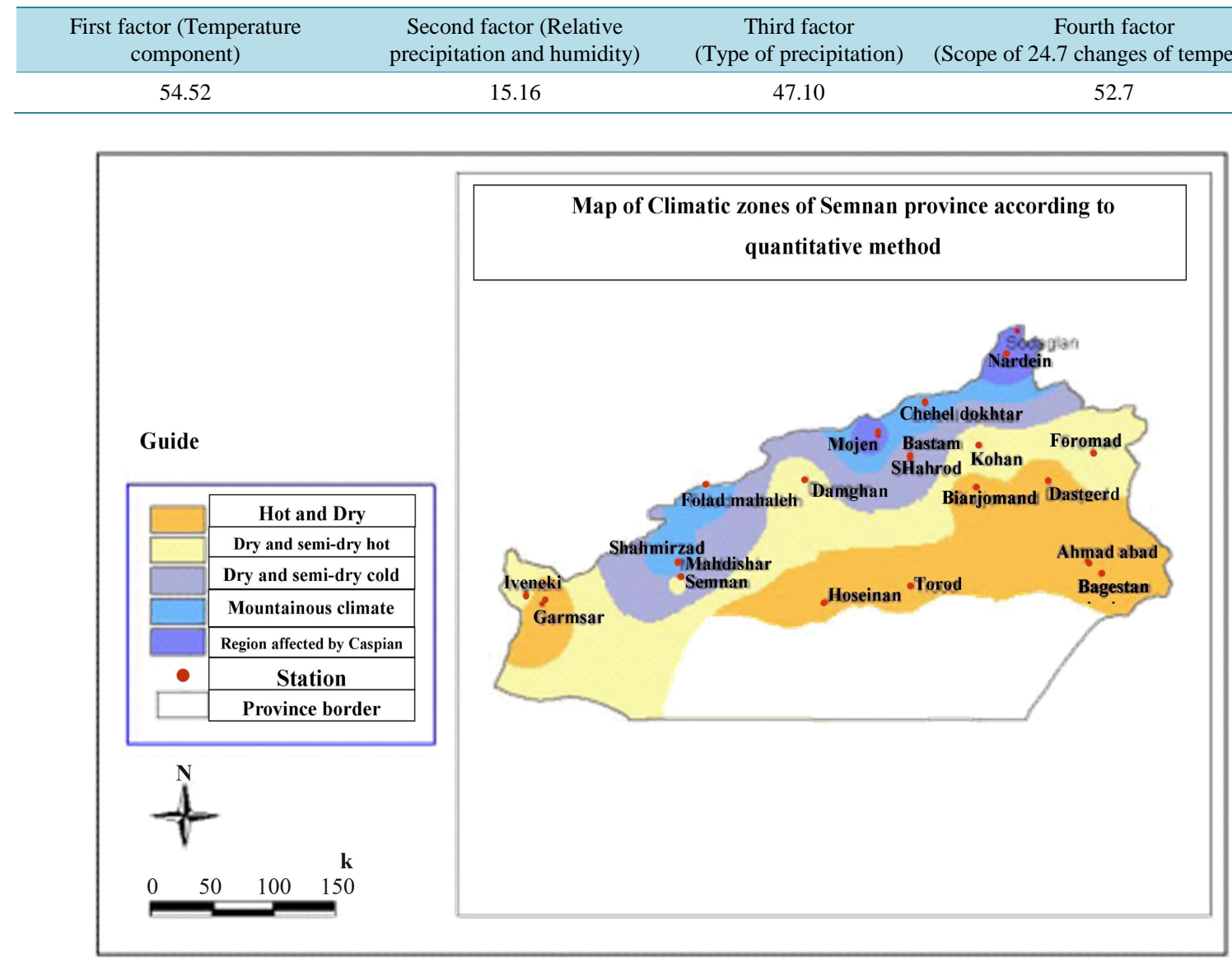

Figure 1. Map of climatic zones of Semnan province according to quantitative method.

lative humidity. Garmsar, Biarjomand, Dastjerd, Taroud, Ahmadabad, Hassinan and Baghestan regions are located in this area.

2) Dry and semi-dry hot

The effects of heat factor and precipitation irregularities could be observed in this region. This region encompasses the central part of the province consisting of Semnan, Ivanaki, Foroumad, Kohan and Damghan.

3) Dry and semi-dry cold

This region consists of parts of central and mountainous regions and has more moderate conditions in comparison with the other two regions. In this region, the effect of temperature, relative humidity and irregular precipitation is quite observable. Shahroud and Bastam are considered as part of this region.

4) Mountainous climate

This region is located in the ring road of north of the province and is known for its cold climate and suitable rain. This region is divisible according to temperature and humidity parameters and encompasses the following regions: Cheheldokhtar, Shahmirzadd, Fouladmahaleh and Mehdishahr.

5) Region affected by Caspian climate

It is a relatively small part of the province which is located in north Alborz and was observable in some areas dispersedly and has the specifications of a humid climate. Sodaghlan, Majan and Nardin areas are located in this region.

\section{Discussion and Conclusion}

Considering the obtained results from climatic types of Semnan province, two different experimental and quantitative methods in connection with architecture within the framework of Table 6, Table 7, Table 8, it could be: 


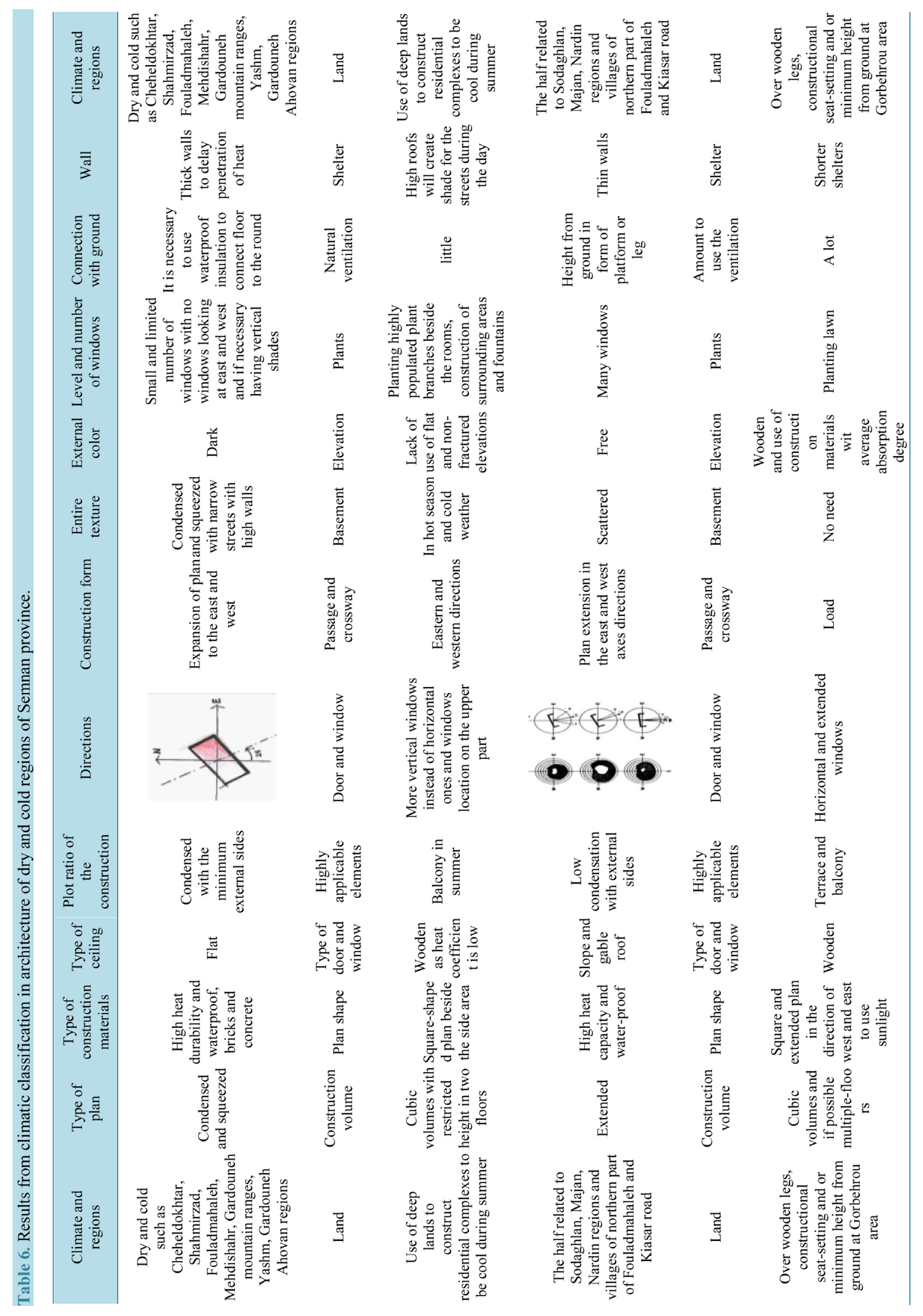




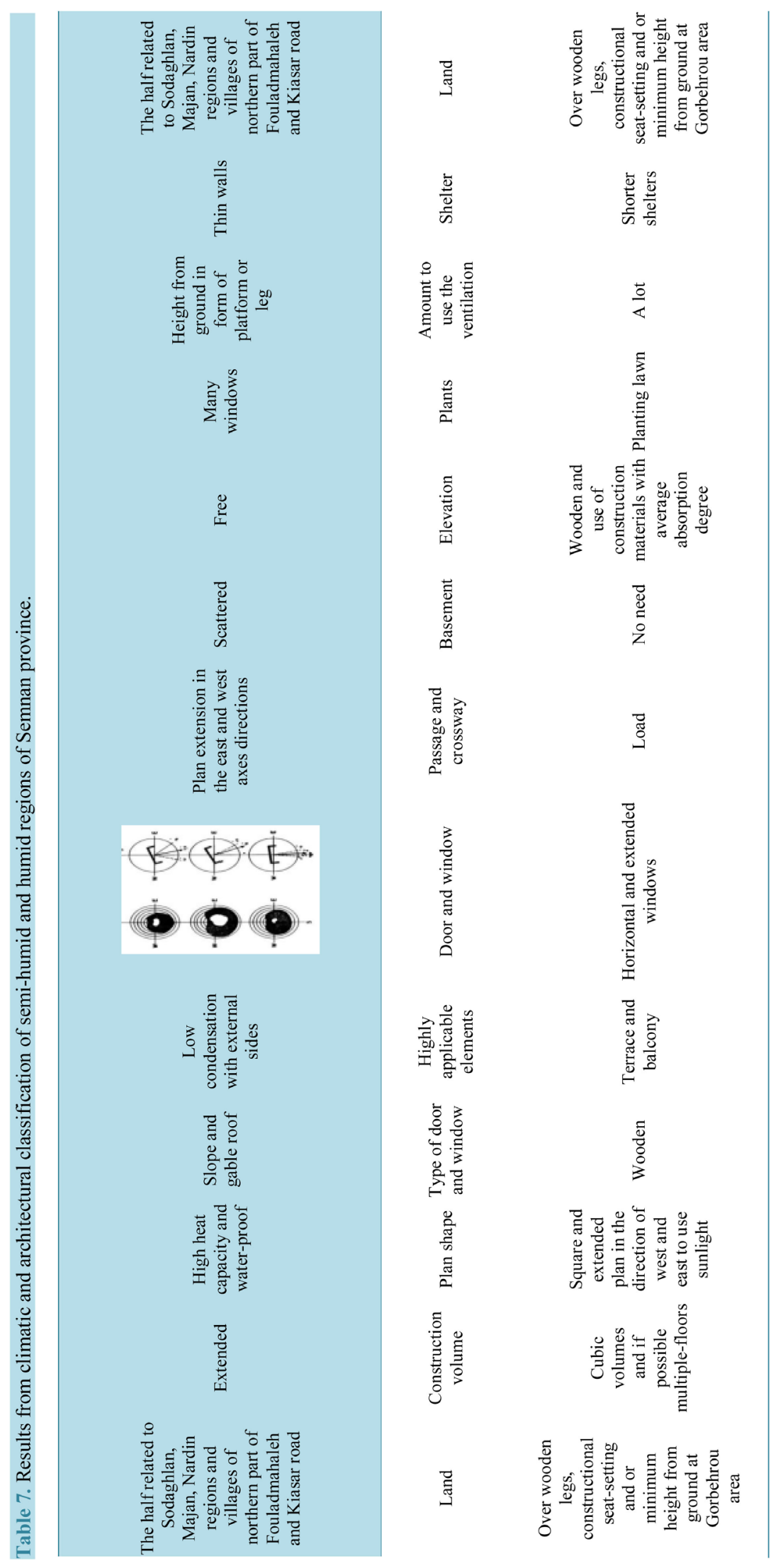




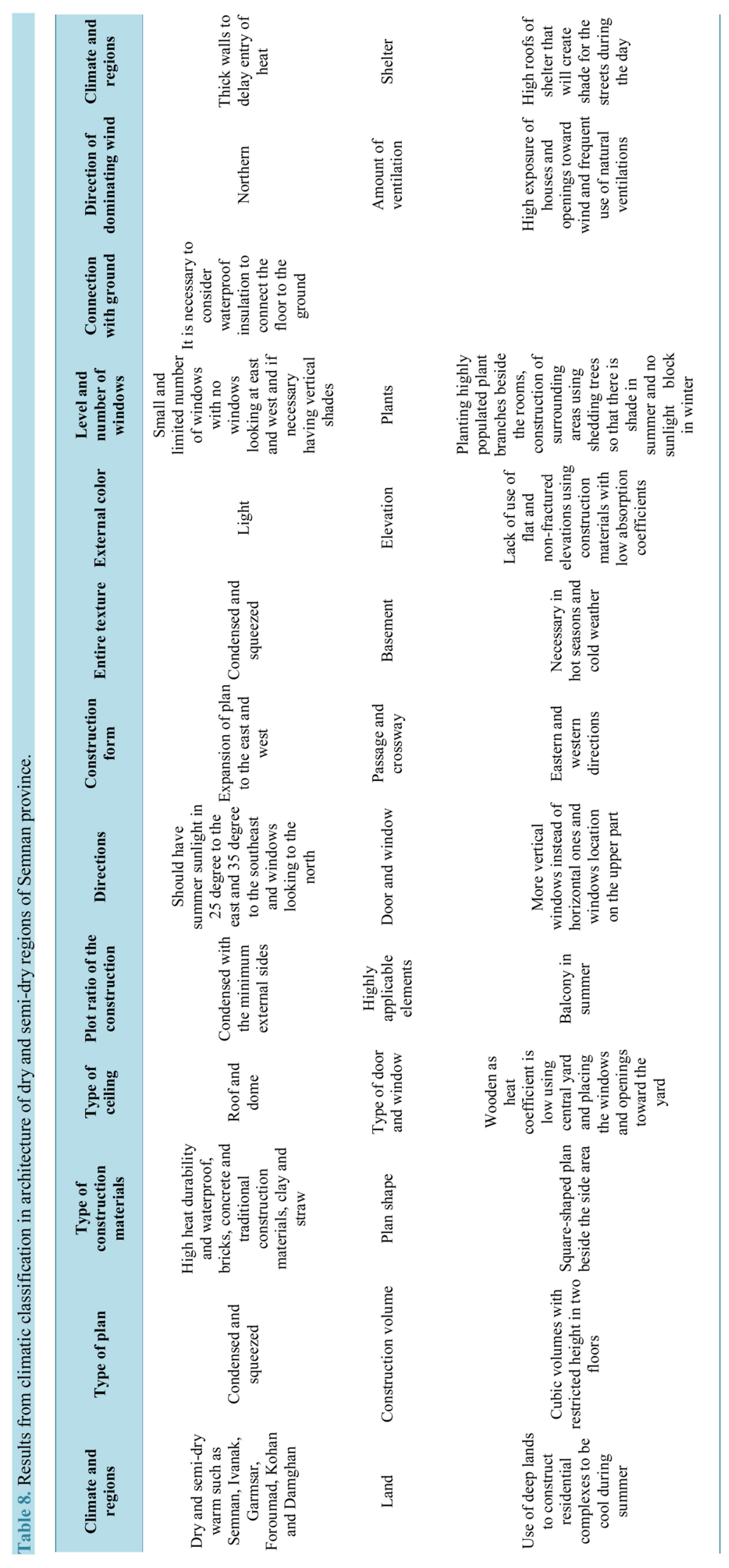




\section{References}

[1] Moradi, S. (2008) Regulation of Environmental Conditions. Shahidi Publication, Tehran.

[2] Ayali, H. (2009) Biomechanical Computations and Climatic Study of Fasa and Its Role to Design Construction in That Region. Fasa Branch, Islamic Azad University, Tehran.

[3] Heidari, H. (1999) Climatic Elements of Iran to Present a Classification Model. PhD Dissertation of Natural Geography, Tarbiat Modarres University, Tehran.

[4] Masoudian, S. (2003) Climatic Regions of Iran. Faculty of Humanities and Social Sciences, Isfahan University, Isfahan.

[5] Zahedi, M. (1993) To Determine Azerbaijan Climate Using Koppen Method. Publication of Faculty of Literature and Humanities, Tabriz University, Tabriz, No. 146.

[6] Alijani, B. (1995), Climate of Iran. Payam-e-Noor Publication, Payam-e-Noor.

[7] White, D. and Richman, M. (1991) Climate Regionalization and Rotation of Principal Components. International Journal of Climatology, 11, 1-25.

[8] Puvaneswaran, M. (1990) Climatic Classification for Queensland Using Multivariate Statistical Techniques. International Journal of Climatology, 10, 591-608. http://dx.doi.org/10.1002/joc.3370100604

[9] Bunkers, M.J., Miler, J.R. and DeGaetano, A.T. (1996) Definition of Climate Regions in the Northern Plains Using an objective Cluster Modification Technique. Journal of Climate, 9, 130-146. http://dx.doi.org/10.1175/1520-0442(1996)009<0130:DOCRIT>2.0.CO;2

[10] Heidari, H. and Alijani, B. (1999) Climatic Classification of Iran Using Multivariate Statistical Techniques of Geographical Researches, No. 37.

[11] Kasmaei, M. (2006) Architecture and Climate. 4th Edition, Soil Publication.

[12] Alizadeh, A. (2001) Principles of Applied Hydrology. 13th Edition, Imam Reza Publication, Mashhad.

[13] Lorenz, E.N. (1956) Empirical Orthogonal Functions and Statistical Weather Prediction Science. Rep, 1, Statistical Forecasting Project Department of Meteorology, MIT, Cambridge.

[14] Mani, B.F.G., Translated by Moqadam, M., et al. (1994) Introduction to Multivariate Methods. Pishtaze Elm Publication, Tehran.

[15] Huth, R. (1996) An Intercomparison of Computer Assisted Circulation Classification Methods. International Journal of Climatology, 16, 893-922.

[16] Kalkstein, L.S., Nichols, M.C., Barthel, C.D. and Greene, J.S. (1996) A New Spatial Synoptic Classification: Application to Air Mass Analysis. International Journal of Climatology, 16, 983-1004. http://dx.doi.org/10.1002/(SICI)1097-0088(199609)16:9<983::AID-JOC61>3.0.CO;2-N 